\title{
Adsorpsi limbah penyamakan krom dengan adsorben karbon aktif dari palm kernel cake (PKC)
}

\section{Adsorption of chrome tanning waste with activated carbon adsorbent from palm kernel cake (PKC)}

\author{
Ageng Priatni", Rihastiwi Setiya Murti, Dona Rahmawati \\ Balai Besar Kulit, Karet dan Plastik, Jl. Sokonandi No. 9, Yogyakarta 55166, Indonesia \\ * Penulis korespondensi. Tel.: +62 274 512929; Faks.: +62 274563655 \\ E-mail: agengpriatni@yahoo.co.id
}

Diterima: 06 April 2020

Direvisi: 16 Mei 2020

Disetujui: 26 Mei 2020

\begin{abstract}
The leather tanning process, a complex process and consists of several steps, where the process involves a large number of water and chemical substances which can cause pollution. The current study provided an investigation on the activated carbon derived from Palm Kernel Cake (PKC) used in the adsorption technology. This activated carbon was considered for reducing total chromium content and BOD, increasing the pH and color of the tanneries wastewater, especially in chrome tanning process. Four variations of activated carbon weight $(1 \mathrm{~g}, 2 \mathrm{~g}, 3 \mathrm{~g}, 4 \mathrm{~g}$, and $5 \mathrm{~g}$ ) were tested in three different temperatures $\left(40^{\circ} \mathrm{C}, 50^{\circ} \mathrm{C}\right.$, and $\left.60^{\circ} \mathrm{C}\right)$ for 30 minutes. After that, the tannery wastewater, which had been adsorbed, was allowed to stand for 24 hours and then filtered. Next, observations on the total chromium content, Biological Oxygen Demand (BOD) level, $p H$, and color of the obtained filtrate were performed. The results showed that the activated carbon successfully adsorbed the pollutant compounds by reducing the total chromium and BOD levels, increasing the $\mathrm{pH}$ and color of tanneries wastewater. In more detail, the findings revealed that the activated carbon could raise the $\mathrm{pH}$ level to 6.6, reduced BOD levels to $50.7 \mathrm{mg} / \mathrm{L}$ with $87.03 \%$ of efficiency, and reduced the total chrome content to $1.03 \mathrm{mg} / \mathrm{L}$ with $99.87 \%$ of efficiency. Besides, the process resulted in tannery wastewater discoloration, from what was originally dark blue to colorless. To conclude, the adsorption for chrome tanning waste adsorption was found performing optimally by using 4 gram of activated carbon at $50^{\circ} \mathrm{C}$.
\end{abstract}

Keywords: activated carbon, adsorption, chrome tanning waste, palm kernel cake, total chrome.

\begin{abstract}
ABSTRAK
Proses penyamakan kulit sangat kompleks dan melalui banyak tahapan, dimana setiap tahapan memerlukan air serta bahan-bahan kimia dalam jumlah besar yang berpotensi menyebabkan terjadinya pencemaran lingkungan. Penggunaan karbon aktif berbahan baku Palm Kernel Cake (PKC) diharapkan mampu mengadsorpsi senyawasenyawa yang menjadi sumber pencemar, seperti menurunkan kadar krom total dan BOD, serta meningkatkan nilai $\mathrm{pH}$ dan warna dari limbah penyamakan kulit, khususnya penyamakan krom. Adsorpsi dilakukan pada suhu $40{ }^{\circ} \mathrm{C}, 50{ }^{\circ} \mathrm{C}$, dan $60{ }^{\circ} \mathrm{C}$ selama 30 menit dengan berat karbon aktif masing-masing $1 \mathrm{~g}, 2 \mathrm{~g}, 3 \mathrm{~g}, 4 \mathrm{~g}$, dan $5 \mathrm{~g}$. Limbah tanning yang telah diadsorpsi, kemudian didiamkan selama 24 jam, dan selanjutnya disaring. Pada filtrat, yang diperoleh, kemudian dilakukan pengamatan terhadap warna, $\mathrm{pH}, \mathrm{BOD}$, serta kadar krom total. Kesimpulan diperoleh bahwa karbon aktif mampu menaikkan pH menjadi 6,6, menurunkan kandungan BOD menjadi 50,7 $\mathrm{mg} / \mathrm{L}$ dengan efisiensi sebesar $87,03 \%$, kadar krom total menjadi $1,03 \mathrm{mg} / \mathrm{L}$ dengan efisiensi penurunan sebesar $99,87 \%$ serta warna limbah yang semula berwarna biru tua menjadi tidak berwarna. Kondisi optimal untuk adsorpsi limbah penyamakan krom adalah suhu $50{ }^{\circ} \mathrm{C}$ dan karbon aktif seberat 4 gram.
\end{abstract}

Kata kunci: adsorpsi, karbon aktif, krom total, limbah penyamakan krom, palm kernel cake. 


\section{PENDAHULUAN}

Proses penyamakan kulit adalah proses mengolah kulit mentah (hide atau skin) menjadi kulit tersamak (leather). Proses tersebut dimaksudkan untuk mengubah sifat-sifat kulit mentah yang mudah mengalami kerusakan dan pembusukan menjadi kulit tersamak yang tahan terhadap aktifitas mikroorganisme dan pembusukan (Prayitno, 2017). Pada industri penyamakan kulit, selain dihasilkan berbagai macam produk utama untuk kebutuhan manusia juga dihasilkan hasil samping yang merugikan manusia sendiri dan lingkungan yaitu berupa limbah cair penyamakan kulit. Limbah cair ini mengandung total padatan, padatan tersuspensi, garam sulfida, zat organik, dan logam krom sehingga memerlukan penanganan secara tepat agar tidak mengganggu lingkungan (Hartanto et al., 1993).

Menurut Brown et al. (2002), proses penyamakan kulit sangat kompleks dan melalui banyak tahapan, dimana setiap tahapan diperlukan air serta bahan-bahan kimia dalam jumlah besar yang berpotensi menyebabkan terjadinya pencemaran lingkungan. Untuk pengolahan 1 (satu) ton kulit mentah, dapat dihasilkan limbah cair sebesar 45-50 liter (Kanagaraj et al., 2006). Adapun sifat-sifat fisis dan kimia dari limbah cair penyamakan kulit dengan volume $0,5-5 \mathrm{~m}^{3} / \mathrm{hari}$, antara lain pH 3,5-4; BOD 1440-2750 mg/L; COD 2748-3132 mg/L; TSS 569-2505 mg/L; minyak/ lemak $100-171 \mathrm{mg} / \mathrm{L}$; krom total $183-270 \mathrm{mg} / \mathrm{L}$; dan sulfida 51-110,5 mg/L (Sunaryo \& Sutyasmi, 2010).

Krom merupakan bahan penyamak yang paling banyak digunakan oleh industri penyamakan kulit. Hal ini dikarenakan proses penyamakan dengan krom yang mudah serta kulit samak yang dihasilkan memiliki suhu kerut yang tinggi, kuat tarik, kelemasan, dan softness yang baik (Nashy et al., 2010). Krom bersama limbah cair yang terbuang merupakan cemaran bahan berbahaya dan beracun (B3), karena krom merupakan jenis limbah logam berat yang bersifat sulit terurai dan dapat terakumulasi dalam tubuh dan lingkungan. Krom murni bersifat tidak toksik, tetapi senyawanya dapat menimbulkan berbagai dampak negatif bagi kesehatan manusia maupun lingkungan, diantaranya ulkus pada kulit dan selaput lendir, zat karsinogen, bersifat racun akut, dan mutagenik melalui pernafasan dan pencernaan. Beberapa penelitian lain juga menunjukan krom valensi tiga dapat berpotensi menyebabkan kanker dan mutasi genetik (Rohaeti, 2007). Parameter lain yang menjadi indikator pencemaran pada limbah penyamakan kulit, selain krom total, adalah $\mathrm{pH}$, warna, BOD, COD, dan lain-lain (Pemprov DIY, 2016). Limbah yang berwarna biru menandakan adanya kandungan krom di dalam limbah, $\mathrm{pH}$ menunjukkan tingkat keasaman dari limbah dan BOD menunjukkan tingginya kandungan bahan organik di dalam limbah.

Saat ini, berbagai teknik pengolahan limbah cair telah dilakukan dan dikembangkan, diantaranya pengolahan secara kimia, fisika, dan biologi. Teknologi kimia yaitu penambahan koagulan merupakan metode yang paling banyak dilakukan. Penggunaan $\mathrm{NaOH}$ sebagai agen presipitasi atau pengendap dapat menurunkan konsentrasi krom dalam limbah penyamakan kulit dengan efisiensi penurunan sebesar 99,34\% pada pH optimum 8 (Meirinna et al., 2013). Sementara menurut Joko (2015), senyawa alkali $\mathrm{Ca}(\mathrm{OH})_{2}$, $\mathrm{NaOH}$, dan $\mathrm{NaHCO}_{3}$ mampu menurunkan konsentrasi kromium dengan efesiensi sebesar $99,28 \%, 99,28 \%$, dan $98,50 \%$ pada $\mathrm{pH}$ optimal 8 dan konsentrasi senyawa alkali sebesar $10 \%$. Pemisahan krom pada limbah cair penyamakan kulit menggunakan gelatin dari hasil hidrolisis trimming kulit domba pikel telah dilakukan dan diperoleh efektifitas sebesar 34,48\% (Sugihartono, 2016). Sementara secara biologi, pengambilan krom dari sludge limbah penyamakan kulit menggunakan biomassa Fusarium sp. telah dilakukan (Triatmojo et al., 2001).

Selain secara kimia dan biologi, cara yang paling sederhana, murah, dan efektif untuk mengatasi atau mengurangi cemaran logam berat, senyawa organik, dan anorganik pada limbah cair, adalah melalui pengolahan secara fisika yaitu menggunakan adsorben karbon aktif. Karbon aktif adalah bahan padat berpori yang berwarna hitam sebagai hasil pembakaran tidak sempurna dalam bentuk granular atau bubuk yang telah melalui proses aktivasi sehingga pori-porinya lebih terbuka dan memiliki luas permukaan yang besar yaitu 300 sampai $3500 \mathrm{~m}^{2} / \mathrm{g}$ (Jati et al., 2012). Aktivasi dilakukan untuk meningkatkan kemampuan adsorpsinya. Adsorpsi adalah terserapnya suatu zat (molekul atau ion) pada permukaan adsorben. Mekanisme adsorpsi digambarkan sebagai proses dimana molekul yang semula ada pada larutan, menempel pada permukaan zat adsorben secara fisika. Suatu molekul dapat teradsorpsi jika gaya adhesi antara molekul adsorbat dengan molekul 
adsorben lebih besar dibanding dengan gaya kohesi pada masing-masing molekul ini. Proses adsorpsi biasanya dilakukan untuk mengurangi senyawa organik yang terdapat dalam limbah cair, sehingga limbah cair dapat dimurnikan. Proses adsorpsi terjadi karena adanya luas permukaan, makin luas permukaan adsorben yang disediakan maka makin banyak molekul yang diserap (Bassett et al., 2013).

Palm kernel cake (PKC) merupakan limbah padat dari inti sawit yang diolah menjadi minyak inti sawit atau biasa disebut Palm kernel oil (PKO). Satu ton inti sawit dapat menghasilkan sekitar 460 kg limbah PKC (Haspiadi \& Sitorus, 2016). PKC bersifat mudah terurai dan dapat menyebabkan bau yang tidak sedap jika tidak diolah dengan benar. Jumlah PKC terus meningkat seiring dengan meningkatnya produksi minyak inti sawit di Indonesia. PKC atau bungkil inti sawit terdiri dari unsur karbon sebesar 96,21\%; nitrogen 2,88\%; fosfat $0,60 \%$; dan kalium sebesar $0,19 \%$ (Kolade et al., 2006). Tingginya kandungan karbon pada PKC berpotensi untuk dikembangkan menjadi karbon aktif.

Pemanfaatan limbah padat PKC sebagai sumber karbon aktif dengan aktivator $\mathrm{H}_{3} \mathrm{PO}_{4}$ dan $\mathrm{KOH}$ telah dilakukan (Haspiadi \& Sitorus, 2016). Karbon aktif dari PKC tersebut juga telah dimanfaatkan sebagai media untuk menurunkan kadar amoniak pada air limbah rumah sakit dengan efektivitas sebesar 94,06\% (Susilowati, 2015). Menurut Priatni et al. (2017), karbon aktif berbahan baku PKC mampu mengadsorpsi logam mangan, timbal, dan besi pada limbah cair laboratorium secara optimal dengan efisiensi penurunan sebesar 79,06\%; 80,94\%; dan 99,54\%.

Limbah penyamakan kulit yang diadsorpsi dengan arang aktif yang dilapisi kitosan, mampu menurunkan kandungan $\mathrm{BOD}_{5}$ sebesar $99,50 \%$ dan krom total sebesar $91,90 \%$ (Lasindrang et al., 2014). Sementara Meirinna et al. (2013) telah membuktikan bahwa karbon aktif dari bagasse fy ash mampu mengadsorpsi krom total dalam limbah cair industri penyamakan kulit dengan efektifitas sebesar 94,99\%. Penggunaan karbon aktif sebagai adsorben telah terbukti mampu menyerap polutan-polutan yang ada pada limbah, namun penelitian penggunaan karbon aktif dari PKC untuk mengurangi polutan pada limbah penyamakan kulit belum dilakukan. Mengingat pentingnya pengolahan limbah penyamakan kulit, khususnya limbah penyamakan krom, serta belum dimanfaatkannya karbon aktif dari PKC sebagai adsorben maka dilakukan penelitian ini dengan tujuan untuk mengetahui efektifitas penggunaan karbon aktif berbahan baku PKC sebagai adsorben. Karbon aktif diharapkan mampu menurunkan kadar krom total, BOD, serta meningkatkan nilai $\mathrm{pH}$ dan warna dalam limbah cair penyamakan kulit, khususnya penyamakan krom.

\section{BAHAN DAN METODE \\ Bahan Penelitian}

Penelitian menggunakan bahan palm kernel cake (PKC) yang diperoleh dari PT. Wilmar Nabati Gresik, Jawa Timur, limbah penyamakan krom yang diperoleh dari Laboratorium Riset Penyamakan Kulit BBKKP Yogyakarta, serta bahan-bahan kimia seperti $\mathrm{H}_{3} \mathrm{PO}_{4}, \mathrm{H}_{2} \mathrm{SO}_{4}, \mathrm{NaOH}$, $\mathrm{HNO}_{3}$, dan kertas saring Whatman 42 yang dibeli dari PT. Merck Jakarta dan PT. Brataco Chemika di Yogyakarta.

\section{Peralatan Penelitian}

Peralatan yang digunakan antara lain Atomic Absorbtion Spectrophotometer (AAS) Shimadzu AA-6800, furnace Thermolyne FB-1400, oven Memmert UF-55, hot magnetic stirrer Thermolyne SP46920-26, pH meter AMTAST AMT20, neraca analitik Mettler Toledo AB204-S, termometer, serta peralatan alat gelas seperti gelas beaker, erlenmeyer, gelas ukur, corong, dan pengaduk.

\section{Metode Penelitian \\ Pembuatan karbon aktif}

PKC ditimbang sebanyak $\pm 500 \mathrm{~g}$ dan dimasukan ke dalam tanur untuk kemudian dipanaskan (dehidrasi) pada suhu $170{ }^{\circ} \mathrm{C}$ selama kurang lebih 2 jam. Selanjutnya suhu pemanasan dinaikkan secara bertahap, yaitu menjadi 300 ${ }^{\circ} \mathrm{C}$ selama \pm 30 menit, dan kemudian $400{ }^{\circ} \mathrm{C}$ selama \pm 30 menit. Setelah proses karbonisasi selesai, karbon yang diperoleh dikeluarkan dan didinginkan di dalam desikator.

Karbon selanjutnya diaktivasi secara kimia dengan larutan $\mathrm{H}_{3} \mathrm{PO}_{4} 6 \%$ dengan cara dipanaskan perlahan-lahan pada suhu $200{ }^{\circ} \mathrm{C}$ dalam ruang asam sampai larutan aktivator tidak ada lagi. Rasio antara aktivator dengan karbon yang belum diaktivasi 1:2 (\% berat). Karbon aktif kemudian ditiriskan dan dicuci dengan aquadest sampai $\mathrm{pH}$ air cucian berkisar antara 6-9. Selanjutnya keringkan kembali di dalam oven pada suhu 105 ${ }^{\circ} \mathrm{C}$ selama \pm 2 jam. 
Tabel 1. Karakteristik limbah penyamakan krom sebelum diadsoprsi dengan karbon aktif.

\begin{tabular}{clccc}
\hline No. & Parameter & Satuan & $\begin{array}{c}\text { Limbah Penyamakan } \\
\text { Krom }\end{array}$ & Perda DIY No. 7 Thn. 2016 \\
\hline 1. & Warna & - & Biru tua (pekat) & - \\
2. & pH & - & 3,9 & $6,0-9,0$ \\
3. & BOD $_{5}$ & $\mathrm{mg} / \mathrm{L}$ & 390,9 & 50,0 \\
\hline
\end{tabular}

\section{Adsorpsi limbah penyamakan krom}

Limbah penyamakan krom sebanyak $250 \mathrm{~mL}$ dimasukkan ke dalam erlenmeyer dan kemudian ditambahkan karbon aktif dengan variasi berat $1,2,3,4$, dan 5 g. Selanjutnya diaduk dengan menggunakan pengaduk magnetik pada kecepatan $400 \mathrm{rpm}$ dan dipanaskan pada variasi suhu 40, 50, dan $60{ }^{\circ} \mathrm{C}$ selama 30 menit. Kemudian didiamkan selama kurang lebih 3 jam dan disaring menggunakan kertas saring Whatman 42. Masingmasing perlakuan diulang sebanyak 3 kali. Pada filrat yang diperoleh kemudian dilihat perubahan warna yang terjadi, $\mathrm{pH}$, dan kadar krom total.

\section{Analisis parameter pencemar}

Analisa parameter dilakukan sebelum dan sesudah proses adsorpsi. Tujuan analisis ini adalah untuk mengetahui penurunan konsentrasi beban pencemar setelah mengalami proses adsorpsi dengan karbon aktif dari PKC. Acuan prosedur penelitian yaitu warna (visual), $\mathrm{pH}$ (SNI-06-6989.11-2004) (BSN, 2004), BOD (SNI 6989.72:2009) (BSN, 2009a), dan krom total (SNI 6989.17:2009) (BSN, 2009b).

\section{HASIL DAN PEMBAHASAN}

\section{Karakterisasi Limbah Penyamakan Krom}

Karakterisasi limbah penyamakan krom ditentukan dari warna, $\mathrm{pH}, \mathrm{BOD}$, dan kadar krom total. Penentuan parameter tersebut

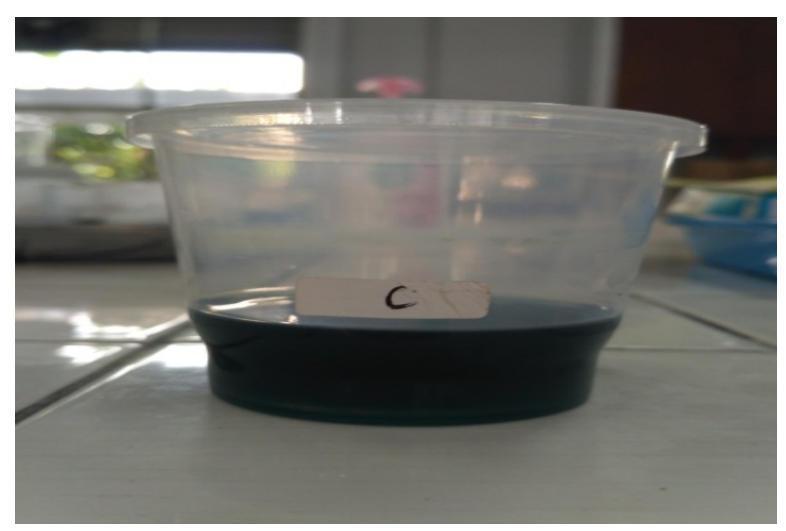

Gambar 1. Warna dari limbah cair penyamakan krom sebelum diadsorpsi dengan karbon aktif. digunakan untuk mengetahui kondisi awal limbah. Karakteristik limbah cair yang dihasilkan dari proses penyamakan krom sebagaimana Tabel 1 .

Tabel 1 menunjukkan bahwa hasil uji untuk limbah penyamakan krom yang dihasilkan masih berada di atas baku mutu air limbah untuk kegiatan industri penyamakan kulit menggunakan krom sebagaimana diatur dalam Perda Daerah Istimewa Yogyakarta No. 7 Tahun 2016 tentang Baku Mutu Air Limbah. Tingginya nilai dari parameter uji tersebut menandakan bahwa masih adanya bahan kimia ataupun senyawa-senyawa organik yang tidak terserap atau tidak bereaksi dengan kulit sehingga terbuang bersama limbah.

Dari Tabel 1 diperoleh kandungan $\mathrm{BOD}_{5}$ sebesar 390,9 mg/L. Tingginya nilai $\mathrm{BOD}_{5}$ menunjukkan tingginya kandungan bahan organik di dalam limbah serta banyaknya oksigen yang diperlukan oleh mikroorganisme untuk mengurai bahan organik yang terlarut dan tersuspensi dalam limbah. Sementara nilai krom total pada limbah penyamakan krom sebesar 787,98 mg/L berasal dari proses tanning yang menggunakan garam krom. Tingginya nilai krom total diduga disebabkan karena tidak semua garam krom bereaksi dengan kulit. Menurut Wiegant (1999) dalam (Prayitno, 2017) bahwa hanya sekitar 70\% garam krom yang masuk dan berikatan dengan serat kulit serta $30 \%$ akan dikeluarkan sebagai limbah. Tingginya krom juga bisa dilihat dari warna air limbah yang berwarna biru tua dan pekat (Gambar 1). Derajat keasaman atau pH dari limbah penyamakan krom yang dihasilkan sebesar 3,9 atau bersifat asam. Rendahnya $\mathrm{pH}$ limbah cair disebabkan penggunaan bahan-bahan kimia sebelum proses dan saat tanning seperti $\mathrm{H}_{2} \mathrm{SO}_{4}$, $\mathrm{HCOOH}, \mathrm{Cr}_{2}\left(\mathrm{SO}_{4}\right)_{3}$, dan $\left(\mathrm{NH}_{4}\right)_{2} \mathrm{SO}_{4}$ (Sunaryo \& Sutyasmi, 2010).

\section{Warna (Visual)}

Secara umum, warna biru tua atau biru kehijauan dari limbah tanning berasal dari garam krom yang digunakan sebagai bahan penyamak (Gambar 1). Semakin tua warna biru dari limbah tanning menunjukkan semakin tinggi kadar krom 


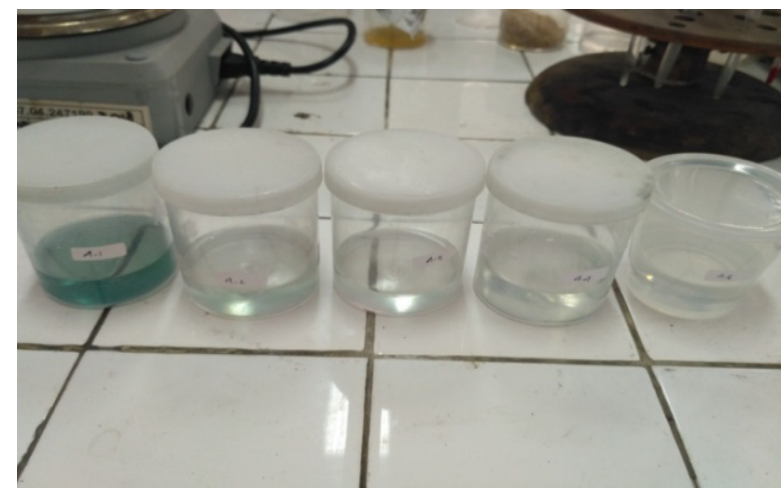

Gambar 2. Warna limbah penyamakan krom hasil adsorpsi pada suhu $40{ }^{\circ} \mathrm{C}$ dengan berat karbon aktif 1, 2, 3, 4, dan 5 gram.

dalam limbah. Limbah cair dengan keadaan demikian sangat berbahaya jika langsung dibuang ke lingkungan atau badan penerima air yang nantinya akan digunakan oleh masyarakat untuk aktivitas mandi, cuci, dan lain-lain.

Gambar 2, 3, dan 4 menunjukkan bahwa penambahan karbon aktif mampu merubah warna limbah penyamakan krom dari biru tua berangsurangsur menjadi tidak berwarna. Ini disebabkan karena karbon aktif mampu menjerap ion krom sehingga kadar krom dalam limbah berkurang dan menyebabkan warna dari limbah menjadi tidak berwarna. Peningkatan kualitas warna ini seiring dengan penurunan kadar krom total sebagaimana Gambar 8. Gambar 2, 3, dan 4 juga

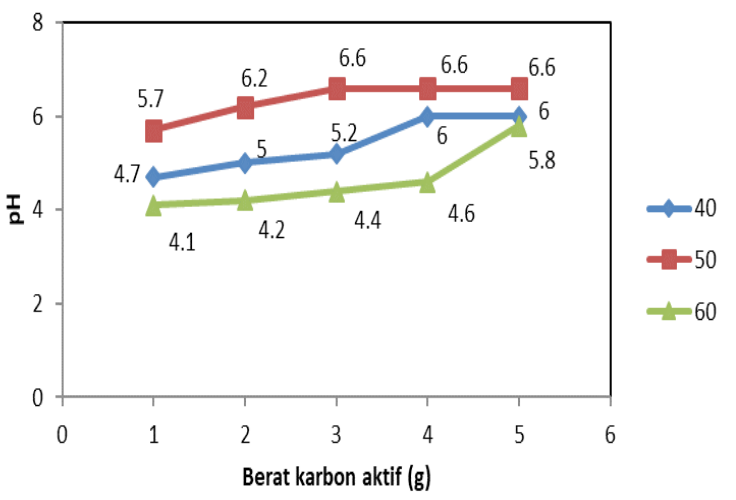

Gambar 5. pH limbah penyamakan krom setelah adsorpsi pada berbagai perlakuan.

menunjukkan bahwa adsorpsi pada suhu $50{ }^{\circ} \mathrm{C}$ menghasilkan warna dengan kualitas yang lebih baik dibandingkan suhu $60^{\circ} \mathrm{C}$ dan $40{ }^{\circ} \mathrm{C}$.

\section{Derajat Keasaman atau pH}

Pengukuran $\mathrm{pH}$ sangat penting sebagai salah satu parameter yang dapat menunjukkan kualitas air. Derajat keasaman juga berpengaruh besar terhadap tumbuh-tumbuhan dan hewan air sehingga dapat digunakan untuk menggambarkan keadaan suatu lingkungan (Pamungkas, 2016). Derajat keasamaan atau $\mathrm{pH}$ dari limbah tanning yang telah diadsorpsi pada suhu $40{ }^{\circ} \mathrm{C}, 50{ }^{\circ} \mathrm{C}$, dan $60{ }^{\circ} \mathrm{C}$ dan berat karbon aktif $1,2,3,4$, dan 5 gram berkisar antara 4,1-6,6. Derajat keasamaan
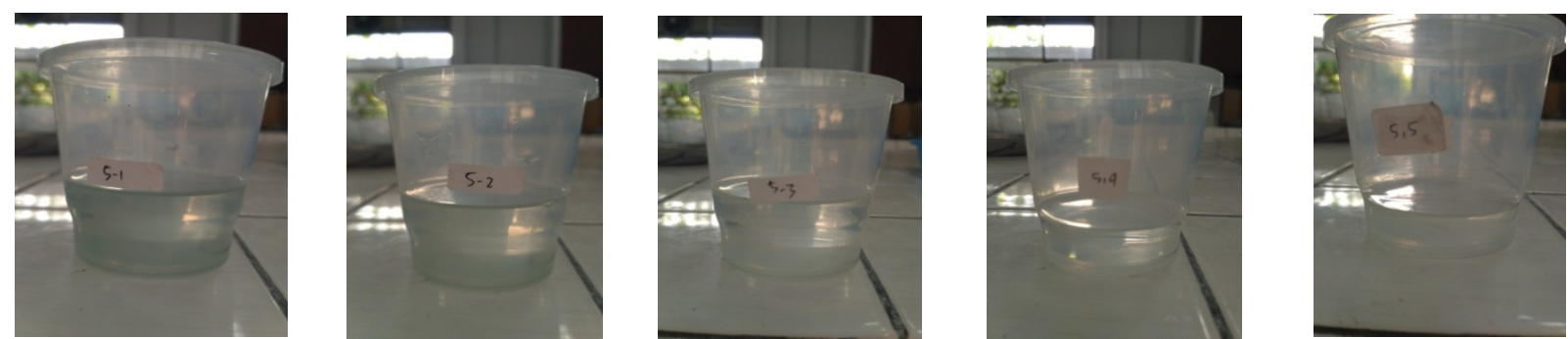

Gambar 3. Warna limbah penyamakan krom hasil adsorpsi pada suhu $50{ }^{\circ} \mathrm{C}$ dengan berat karbon aktif $1,2,3,4$, dan 5 gram.
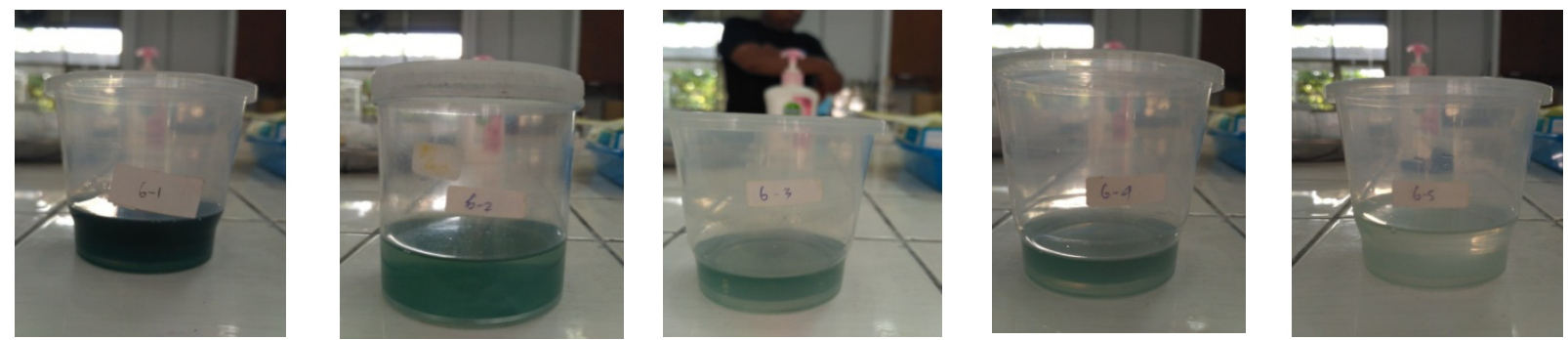

Gambar 4. Warna limbah penyamakan krom hasil adsorpsi pada suhu $60{ }^{\circ} \mathrm{C}$ dengan berat karbon aktif $1,2,3,4$, dan 5 gram. 
atau $\mathrm{pH}$ terendah yaitu 4,1 diperoleh pada kondisi suhu adsorpsi $60^{\circ} \mathrm{C}$ dan berat karbon aktif 1 gram, sementara $\mathrm{pH}$ tertinggi yaitu 6,6 diperoleh pada kondisi suhu $50{ }^{\circ} \mathrm{C}$ dan berat karbon aktif 3, 4, dan 5 gram (Gambar 5). pH 6,6 yang dihasilkan setelah adsorpsi sudah memenuhi baku mutu air limbah untuk kegiatan industri penyamakan kulit khususnya penyamakan menggunakan krom (chrome tanning) yang diatur dalam Perda DIY No. 7 Tahun 2016 yaitu 6,0-9,0.

Derajat keasaman atau $\mathrm{pH}$ limbah penyamakan krom mengalami kenaikan seiring meningkatnya suhu adsorpsi hingga $50{ }^{\circ} \mathrm{C}$ dan menurun ketika suhu adsorpsi ditingkatkan menjadi 60 ${ }^{\circ} \mathrm{C}$. Begitu pula dengan karbon aktif, semakin banyak jumlah karbon yang ditambahkan maka $\mathrm{pH}$ semakin meningkat dan cenderung tetap pada berat karbon 3, 4, dan 5 gram (Gambar 5). Kenaikan $\mathrm{pH}$ disebabkan karena peningkatan suhu menyebabkan pori-pori dari karbon aktif menjadi semakin terbuka sehingga daya serap meningkat. Begitu juga dengan semakin banyaknya jumlah karbon aktif yang ditambahkan akan memperluas bidang kontak antara adsorben (karbon aktif) dan adsorbat sehingga semakin banyak ion-ion yang terikat, khususnya dari senyawa $\mathrm{H}_{2} \mathrm{SO}_{4}, \mathrm{HCOOH}$, $\mathrm{Cr}_{2}\left(\mathrm{SO}_{4}\right)_{3}$, dan $\left(\mathrm{NH}_{4}\right)_{2} \mathrm{SO}_{4}$, yang berakibat meningkatnya $\mathrm{pH}$ limbah. Menurut Syauqiah et al. (2011), semakin besar kecepatan pengadukan, lama waktu kontak, dan pemanasan yang digunakan, maka proses penyerapan adsorbat oleh adsorben menjadi lebih baik.

Derajat keasaman atau $\mathrm{pH}$ yang menurun pada suhu $60{ }^{\circ} \mathrm{C}$ dikarenakan reaksi adsorpsi yang bersifat irreversible telah mencapai kesetimbangannya, serta penambahan karbon

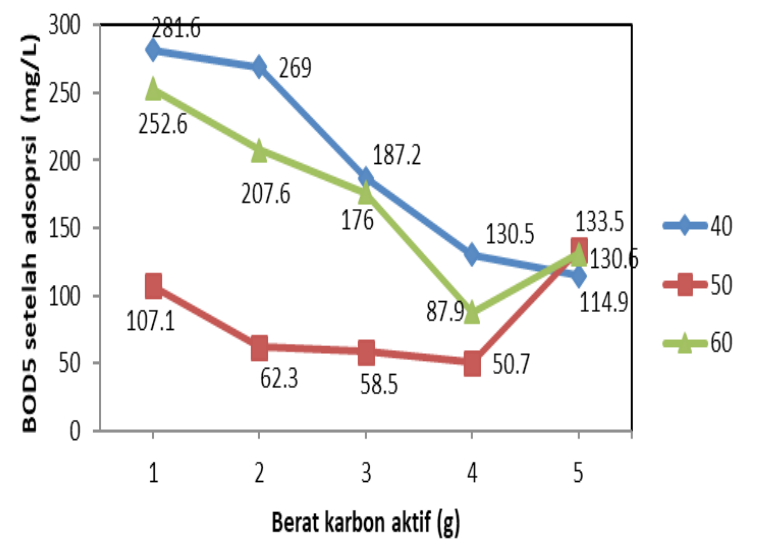

Gambar 6. $\mathrm{BOD}_{5}$ limbah penyamakan krom setelah adsorpsi pada berbagai perlakuan. aktif sebesar 4 dan 5 gram yang bersifat excess atau berlebih sehingga reaksi adsorpsi menjadi jenuh. Menurut Notodarmojo (2005), proses sorpsi umumnya berjalan dengan cepat pada tahap awal, kemudian cenderung tetap dan perlahan-lahan akan menurun, yang disebut kondisi keseimbangan. Keseimbangan yang dimaksud yaitu dimana laju sorpsi sama dengan laju desorpsi.

\section{Biochemical Oxygen Demand (BOD $)_{5}$}

Biochemical Oxygen Demand atau $\mathrm{BOD}_{5}$ merupakan parameter utama untuk mengetahui jumlah oksigen yang diperlukan oleh mikroorganisme untuk menguraikan bahan organik yang terlarut dan tersuspensi dalam air buangan secara biologi (Ginting, 2007). Pemeriksaan $\mathrm{BOD}_{5}$ diperlukan untuk menentukan beban pencemaran akibat air limbah penyamakan. $\mathrm{BOD}_{5}$ dari proses adsorpsi dengan karbon aktif sebagaimana Gambar 6.

Kandungan $\mathrm{BOD}_{5}$ dari limbah tanning yang telah diadsorpsi pada suhu 40, 50, dan $60{ }^{\circ} \mathrm{C}$ dan berat karbon aktif 1, 2, 3, 4, dan 5 gram berkisar antara 50,70-281,60 mg/L. Kandungan $\mathrm{BOD}_{5}$ tertinggi yaitu $281,60 \mathrm{mg} / \mathrm{L}$ diperoleh pada kondisi suhu adsorpsi $40{ }^{\circ} \mathrm{C}$ dan berat karbon aktif 1 gram dengan efisiensi penurunan sebesar $27,96 \%$. Kandungan $\mathrm{BOD}_{5}$ terendah yaitu 50,70 $\mathrm{mg} / \mathrm{L}$ dengan efisiensi sebesar $87,03 \%$ diperoleh pada kondisi suhu $50{ }^{\circ} \mathrm{C}$ dan berat karbon aktif 4 gram (Gambar 6 dan 7). Nilai kandungan $\mathrm{BOD}_{5}$ terendah yang diperoleh yaitu $50,70 \mathrm{mg} / \mathrm{L}$ sudah mendekati baku mutu air limbah untuk kegiatan industri penyamakan kulit khususnya penyamakan menggunakan krom (chrome tanning) yang diatur dalam Perda DIY No. 7 Tahun 2016 yaitu 50 mg/L.

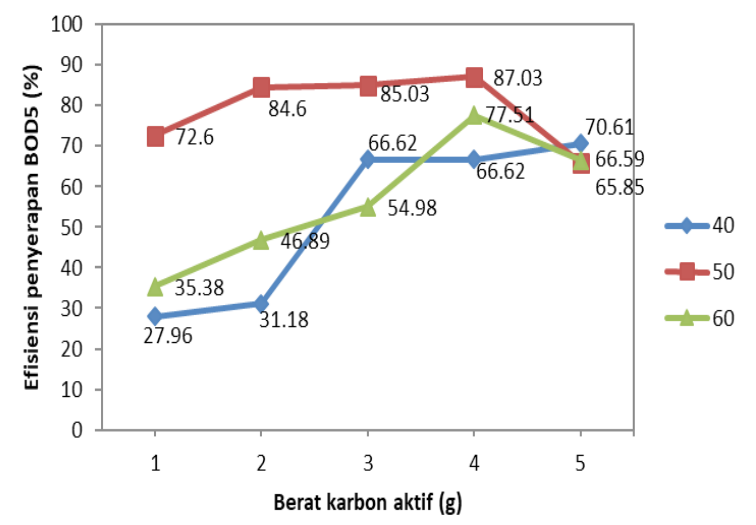

Gambar 7. Efisiensi penyerapan karbon aktif terhadap $\mathrm{BOD}_{5}$ dari limbah penyamakan krom pada berbagai perlakuan. 
Efisiensi penurunan yang diperoleh masih lebih rendah dibandingkan dengan yang dilakukan oleh Lasindrang et al., (2014), dimana kitosan yang melapisi arang aktif memiliki gugus amino dan derajat deasetilasi yang tinggi sehingga mampu mengikat logam, protein, dan zat warna (Zakaria et al., 2002), dan dapat mengadsorpsi BOD lebih efektif.

$\mathrm{BOD}_{5}$ mencerminkan tingkat pencemaran suatu badan air oleh buangan organik, semakin tinggi nilai $\mathrm{BOD}_{5}$ berarti semakin besar tingkat pencemaran (Pamungkas, 2016). Kandungan $\mathrm{BOD}_{5}$ mengalami penurunan hingga suhu $50{ }^{\circ} \mathrm{C}$ dan berat karbon aktif hingga 4 gram. Penurunan kandungan $\mathrm{BOD}_{5}$ terjadi dikarenakan kenaikan suhu menyebabkan reaksi adsorpsi berlangsung lebih cepat sehingga semakin banyak zat-zat organik yang terserap oleh karbon aktif serta luasnya permukaan kontak. Menurut Effendi (2003), aktivitas biologis serta reaksi-reaksi kimia akan meningkat dua kali lipat setiap kenaikan temperatur $10{ }^{\circ} \mathrm{C}$.

Namun peningkatan suhu $60{ }^{\circ} \mathrm{C}$ dan berat karbon aktif 5 gram (Gambar 6) menyebabkan kandungan $\mathrm{BOD}_{5}$ kembali tinggi yang menandakan zat-zat organik di dalam air limbah meningkat Hal ini karena selain menaikan kecepatan reaksi, peningkatan suhu juga menyebabkan kematian migroorganisme yang sifatnya tidak tahan terhadap suhu tinggi sehingga kemampuan untuk menguraikan zat-zat organik menurun. Selain itu, penambahan karbon aktif 5 gram menyebabkan reaksi adsorpsi menjadi jenuh.

\section{Krom Total}

Garam krom yang digunakan dalam

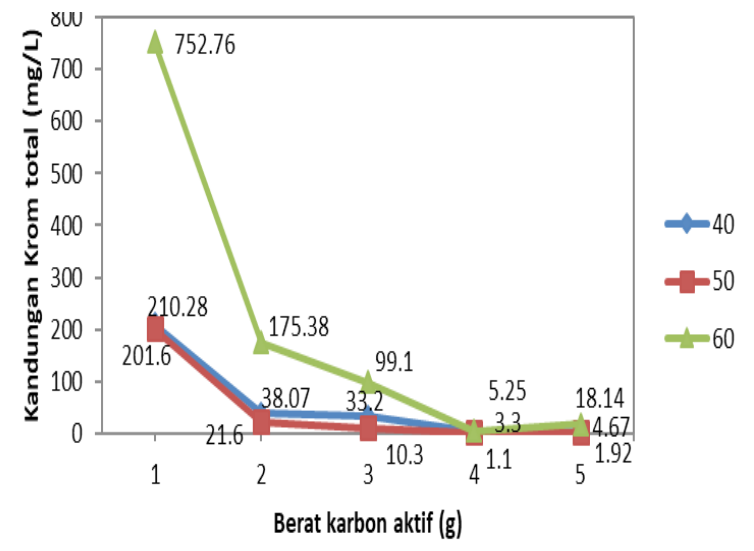

Gambar 8. Krom total limbah penyamakan krom setelah adsorpsi pada berbagai perlakuan. penyamakan kulit pada umumnya adalah garam kromium bervalensi 3 dalam bentuk $\mathrm{Cr}_{2}\left(\mathrm{SO}_{4}\right)_{3}$ serta memiliki basisitas yang rendah, yaitu kurang lebih $33,33 \%$. Tujuannya adalah agar garam krom dapat masuk jauh ke dalam jaringan kulit dan bereaksi dengan protein kolagen. Kemudian, basisitas ditingkatkan dengan penambahan natrium asetat atau natrium bikarbonat agar ikatan yang terjadi antara krom dengan gugus hidroksil kolagen tidak lepas (Prayitno, 2017). Garam krom yang tidak bereaksi dengan kulit akan terbuang bersama limbah cair. Krom total dari proses adsorpsi dengan karbon aktif sebagaimana Gambar 8.

Kadar krom total dari limbah penyamakan krom yang telah diadsorpsi berkisar antara 1,03$752,76 \mathrm{mg} / \mathrm{L}$, dimana nilai untuk krom total tertinggi yaitu $752,76 \mathrm{mg} / \mathrm{L}$ dengan efisiensi penurunan sebesar $4,47 \%$ diperoleh pada suhu adsorpsi $60{ }^{\circ} \mathrm{C}$ dan berat karbon aktif 1 gram. Kadar krom total terendah yaitu $1,03 \mathrm{mg} / \mathrm{L}$ dengan efisiensi penurunan sebesar $99,87 \%$ diperoleh pada suhu adsorpsi $50{ }^{\circ} \mathrm{C}$ dan berat karbon aktif 3 gram (Gambar 8 dan 9). Nilai kadar krom total terendah yang diperoleh yaitu $1,03 \mathrm{mg} / \mathrm{L}$ masih berada di atas baku mutu air limbah untuk kegiatan industri penyamakan kulit khususnya penyamakan menggunakan krom (chrome tanning) yang diatur dalam Perda DIY No. 7 Tahun 2016 yaitu $0,5 \mathrm{mg} / \mathrm{L}$. Namun, efisiensi penurunan krom total yang diperoleh yaitu $99,87 \%$ lebih besar dibandingkan dengan limbah penyamakan kulit yang diadsorpsi dengan karbon aktif komersial + $\mathrm{TiO}_{2}$ (nanokomposit) yaitu sebesar $95,93 \%$ (Jati et al., 2012) dan yang diadsorpsi dengan karbon aktif dari bagase fly ash yaitu 94,99\% (Meirinna et al., 2013). Menurut Lasindrang et al. (2014), limbah

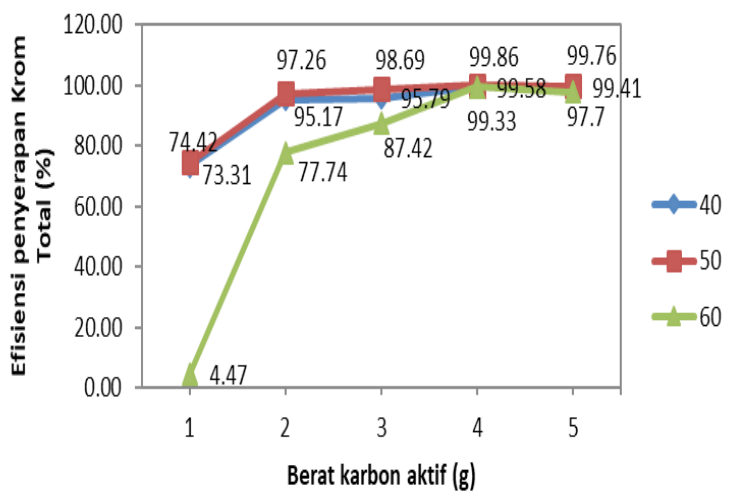

Gambar 9. Efisiensi penyerapan karbon aktif terhadap krom total dari limbah penyamakan krom pada berbagai perlakuan. 
penyamakan kulit yang diadsorpsi dengan arang aktif yang dilapisi kitosan mampu menurunkan krom total sebesar 91,90\%.

Pada Gambar 8 diketahui bahwa terjadi penurunan kadar krom total ketika suhu adsorpsi dinaikan hingga $50 \quad{ }^{\circ} \mathrm{C}$. Peningkatan suhu menyebabkan pori-pori karbon aktif semakin terbuka sehingga semakin banyaknya ion-ion logam krom yang terserap dan membentuk ikatan kovalen dengan karbon aktif. Peningkatan suhu juga menyebabkan karbon aktif menjadi lebih reaktif sehingga tumbukan yang terjadi antara molekul krom hidroksida dan karbon aktif menjadi lebih cepat sehingga terjadi penurunan kadar krom dalam limbah.

Selain peningkatan suhu, penambahan karbon aktif hingga 3 gram juga menyebabkan penurunan kadar krom total. Penambahan karbon aktif menyebabkan bidang kontak antara karbon aktif dan ion logam yaitu krom hidroksida semakin luas. Menurut Reynolds (1982), semakin luas permukaanadsorbenmakasemakinbanyakzatyang teradsorpsi. Luas permukaan adsorben ditentukan oleh ukuran partikel dan jumlah dari absorben. Peningkatan kembali kadar krom total pada suhu $60{ }^{\circ} \mathrm{C}$ dan penambahan karbon aktif sebesar 5 gram (Gambar 8) diduga dikarenakan pemanasan tinggi yang mengakibatkan kesetimbangan reaksi adsorpsi berbalik kearah kiri sehingga ikatan kovalen yang terbentuk terlepas dan sebagian ionion krom terlarut kembali ke dalam limbah cair.

\section{KESIMPULAN}

Karbon aktif dari PKC mampu menaikkan pH limbah penyamakan krom menjadi 6,6, menurunkan kandungan BOD menjadi $50,7 \mathrm{mg} / \mathrm{L}$ dengan efisiensi sebesar $87,03 \%$, kadar krom total menjadi $1,03 \mathrm{mg} / \mathrm{L}$ dengan efisiensi penurunan sebesar $99,87 \%$ serta warna limbah yang semula berwarna biru tua menjadi tidak berwarna. Kondisi optimal untuk adsorpsi limbah penyamakan krom adalah suhu $50{ }^{\circ} \mathrm{C}$ dan karbon aktif seberat 4 gram.

\section{UCAPAN TERIMA KASIH}

Terima kasih diucapkan kepada Kepala Balai Besar Kulit, Karet dan Plastik Yogyakarta atas sarana dan prasarana yang diberikan serta pihakpihak yang terlibat penelitian ini.

\section{DAFTAR PUSTAKA}

Bassett, J., Denney, R. C, Jeffery, G. H., \& Mendham, J.
(2013). Buku ajar Vogel: Kimia analisis kuantitatif anorganik. Jakarta, Indonesia: EGC.

Brown, E. M., Latona, R. J., Taylor, M. M., \& Garcia, R. A. (2012). Effects of pretanning processes bovine hide collagen structure. Journal of the American Leather Chemists Association, 107, 1-7.

BSN (Badan Standardisasi Nasional). (2004). Air \& Air Limbah Bagian 11. Cara uji $\mathrm{pH}$ dengan alat $\mathrm{pH}$ meter (SNI-06-6989.11-2004). Jakarta, Indonesia: BSN.

BSN (Badan Standardisasi Nasional). (2009a). Air \& Air Limbah Bagian 72. Cara uji BOD (SNI 6989.72:2009). Jakarta, Indonesia: BSN.

BSN (Badan Standardisasi Nasional). (2009b). Air \& Air Limbah Bagian 17. Cara uji krom total (Cr-T) secara SSA-nyala (SNI 6989.17:2009). Jakarta, Indonesia: BSN.

Effendi, H. (2003). Telaah kualitas air bagi pengelolaan sumber daya dan lingkungan perairan. Yogyakarta, Indonesia: Kanisius.

Ginting, P. (2007). Sistem pengelolaan lingkungan dan limbah industri. Bandung, Indonesia: Yrama Widya.

Hartanto, E. S., Bastaman, S., \& Citroreksoko, P. (1993). Pengaruh penambahan khitosan dan lama pengendapan terhadap hasil penanganan limbah cair industri penyamakan kulit. Warta Industri Hasil Pertanian, 10(1-2), 14-17.

Haspiadi, H., \& Sitorus, S. (2016). Pemanfaatan limbah padat palm kernel cake (PKC) sebagai sumber karbon aktif dengan proses kimia. Jurnal Riset Teknologi Industri, 10(1), 24-35.

Jati, B. N., Naimah, S., Aviandharie, S. A., \& Ermawati, R. (2012). Komposit nano $\mathrm{TiO}_{2}$ dengan PCC, zeolit atau karbon aktif untuk menurunkan total krom dan zat organik pada air limbah industri penyamakan kulit. Jurnal Kimia Kemasan, 34(1), 231-236. https://doi.org/10.24817/jkk. v34i1.1858

Joko, T. (2015). Penurunan kromium (Cr) dalam limbah cair proses penyamakan kulit menggunakan senyawa alkali $\mathrm{Ca}(\mathrm{OH})_{2}, \mathrm{NaOH}$, dan $\mathrm{NaHCO}_{3}$ (Studi kasus di PT Trimulyo Kencana Mas Semarang). Jurnal Kesehatan Lingkungan Indonesia, 2(2), 39-45.

Kanagaraj, J., Velapan, K. C., Babu, N. K. C., \& Sadulla, S. (2006). Solid wastes generation in the leather industry and its utilization for cleaner environment - A review. Journal of Scientific and Industrial Research, 65(7), 541-548.

Kolade, O. O., Coker, A. O., Shridar, M. K. C., \&Adeoye, G. O. (2006). Palm kernel waste management through composting and crop production. Journal of Environmental Health Research, 5(2), 81-85.

Lasindrang, M., Suwarno, Hadisusanto, Tandjung, S. D., \& Nitisastro, K. H. (2014). Adsorpsi pencemaran limbah cair industri penyamakan kulit 
oleh kitosan yang melapisi arang aktif temprung kelapa. Jurnal Teknosains, 3(2), 132-141. https:// doi.org/10.22146/teknosains.6026

Meirinna, Fahrurozi, \& Santosa, S. J. (2013). Sistem penurunan kadar krom (III) limbah cair penyamakan kulit dengan kombinasi presipitasi menggunakan natrium hidroksida dan adsorpsi menggunakan bagase fly ash. ASEAN Journal of System Engineering, 1(2), 62-67.

Nashy, E. H. A., Huseein, A. I., \& Essa, M. M. (2010). Retanning agents for chrome tanned leather based on emulsion nano-particles of styrene/buthyl acrylate copolymers. New York Science Journal, 3(11), 13-21.

Notodarmojo, S. (2005). Pencemaran tanah dan air tanah. Bandung, Indonesia: ITB Press.

Pamungkas, M. O. (2016). Studi pencemaran limbah cair dengan parameter $\mathrm{BOD}_{5}$ dan $\mathrm{pH}$ di pasar ikan tradisional dan pasar modern di Kota Semarang. Jurnal Kesehatan Masyarakat, 4(2), 166-175.

Pemprov DIY (Pemerintah Provinsi DIY). (2016). Perda DIY No. 7 Tahun 2016 tentang baku mutu air limbah. Yogyakarta, Indonesia: Pemprov DIY.

Prayitno. (2017). Teknologi bersih proses penyamakan kulit. Yogyakarta, Indonesia: CV. Grafika Indah.

Priatni, A., Rusdiansyah, \& Sitorus, S. (2017). Efektivitas karbon aktif dari palm kernel cake sebagai adsorben ion logam $\mathrm{Mn}, \mathrm{Fe}$ dan $\mathrm{Pb}$ pada air limbah AAS terkonsentrat. Prosiding Seminar Nasional ke-1 Baristand Industri Samarinda, 1, 250-264.

Reynolds, T. D. (1982). Unit operation and process in environmental engineering. Texas, USA: Woods
Worths Inc.

Rohaeti,E.(2007).Pencegahanpencemaran lingkungan oleh logam berat krom limbah cair penyamakan kulit (Studi kasus di Kabupaten Bogor) (Disertasi). Institut Pertanian Bogor, Indonesia.

Sugihartono. (2016). Pemisahan krom pada limbah cair industri penyamakan kulit menggunakan gelatin dan flokulan anorganik. Majalah Kulit, Karet, dan Plastik, 32(1), 21-30. https://doi.org/10.20543/ mkkp.v32i1.900

Susilowati. (2015). Efektivitas pemanfaatan karbon aktif limbah inti sawit sebagai media penurunan kadar amoniak dalam air limbah RS Dirgahayu Kec. Samarinda Ulu Kota Samarinda (Skripsi). Universitas Widya Gama Mahakam, Indonesia.

Sunaryo, I., \& Sutyasmi, S. (2010). Pengolahan limbah cair laboratorium riset penyamakan kulit di Balai Besar Kulit, Karet dan Plastirk (BBKKP). Jurnal Riset Industri, 4(3), 61-72.

Syauqiah, I., Amalia, M., \& Kartini, H. A. (2011). Analisis variasi waktu dan kecepatan pengadukan pada proses adsorbsi limbah logam berat dengan arang aktif. Info Teknik, 12(1), 11-20.

Triatmojo, S., Sihombing, D. T. H., Djojowidagdo, S., \& Wiradarya, T. R. (2001). Biosorpsi dan reduksi krom limbah penyamakan kulit dengan biomassa Fusarium sp dan Aspergillus niger. Jurnal Manusia dan Lingkungan, 8(2), 78-81.

Zakaria, M. B., Jais, M., Ahmad, W. Y., \& Othman, M. R. (2002). Penurunan kekeruhan efluen industri minyak sawit (EIMS) oleh koagulan konvensional dan kitosan. Prosiding Seminar Kimia Bersama UKM-ITB ke-5, 1, 487-492. 
